\title{
Editorial
}

\section{Generational Legacies} The Family in Chinese Christianity

\author{
Chris White \\ Cornerstone Integrated Liberal Arts, Purdue University, West Lafayette, \\ Indiana, USA \\ chrismwhite@purdue.edu
}

In the fall of 2019, the Center on Religion and Chinese Society (now the Center on Religion and the Global East) at Purdue University issued a call for applications for a symposium on the family in Chinese Christianity, to be held in May 2020. My own fieldwork and archival research on Protestantism in South Fujian had continuously pointed out to me the significance of family as integral to understanding Chinese Christians, both in the past and today. Interest in the topic from other scholars was apparent, as we received dozens of applications to attend the symposium. Unfortunately, the global pandemic thwarted our plans, but the enthusiastic response prompted the crafting of this special issue. In early 2021, a call for papers for this special issue was announced. Again, the response from scholars revealed a great interest in the topic, as we received many full-paper submissions. Five scholars were chosen to attend a virtual workshop in April 2021 to discuss their papers and the general theme. The revised versions of these papers are presented here in this special issue.

Since the late Ming Dynasty, issues related to family have been a challenge for missionaries and Chinese Christians alike. One of the first obstacles that many Chinese Christian converts were confronted with centered on ancestor "worship" and whether Christianity allowed rituals associated with this. The infamous Rites Controversy pitted Matteo Ricci's Jesuits, who 
took an accommodationist position vis-à-vis Chinese ancestral rites, against Dominican and Franciscan missionaries, who successfully lobbied their case in Rome. Pope Clement XI officially banned such rituals for Chinese Catholics in 1704, which instigated the Kangxi Emperor to respond by banning missionaries who did not follow Ricci's position. At the end of the Qing Dynasty, the veneration of ancestors was still a major concern for Chinese Christianity, but by this time Protestants had joined the debate. In the three large Protestant missionary conferences held in China in 1877,1890 , and 1907, "ancestor worship" occupied hours of debate and took up more space in the published proceedings of these conferences than any other topic.

By and large, Protestant missionaries condemned the "heathen ceremonies" connected to ancestors, such as bowing at graves or offering food and incense at ancestral halls, and encouraged Chinese Christians to steadfastly refuse to participate in these rituals. Spurning such activities was a contentious act, and early converts to Christianity in particular were often ostracized from their lineage and abused by relatives for forsaking their forefathers. Not only did many Chinese Christians reject certain ceremonies related to ancestors, they also often refused to contribute obligatory funds for lineage-based activities on the basis that their religious faith precluded this. The disposal of ancestral tablets by some Chinese Christians, often done in a performative fashion or by publicly handing them over to missionaries, further defined the chasm between Christian and non-Christian extended family members.

Christianity caused significant rupture to the Chinese family order not only at the lineage level but also within smaller family units, and particularly in terms of gendered familial roles. This is apparent in the articles in this special issue. It was not the original intent for this special issue to focus on gender issues in the history of Chinese Christianity, but four of the five papers do this. It is ironic, though not coincidental, that in China, typically (and historically) considered a very patriarchal society, much of the emphasis on making Christian families centered on women. Ideas related to the roles of females, such as gender equality, girls' education, and companion marriage, were championed by churches decades before they were promoted by New Culture Movement urban intellectuals.

As shown by Anneke Stasson in the first article, the cultural and societal byproducts of Christianity were often revolutionary for Chinese Christians, particularly females. Churches encouraged converts to form new opinions and adopt new practices as daughters were educated and wives were given greater freedom. Christianity offered Chinese females new options that were not common in the traditional Chinese value system. For instance, Stasson shows how a disproportionate number of Chinese Christian females chose not to marry. 
Nearly three decades after the founding of Hwa Nan, a women's college in Fuzhou, over 70 percent of the graduates (178 in total) had not married. Even though many missionary reports talk about female education as a primary way to prepare wives for male pastors and church members, it is clear that compared to traditional Chinese culture, Christianity placed females in an elevated position that afforded new freedoms which were transformational for many individuals.

In the second article, Yun Zhou uses Republican-era Christian publications to reveal how the ideal of a Christian family was promoted by missionaries and Chinese Christians alike. Females typically are not thought of as central to the formation of Chinese theology, but this is partially due to how theology is understood. Systematic theology or formal theology taught in seminaries is not the only form of theology. Writing plays or publishing magazines aimed at women from a Christian perspective were important ways that females shaped Chinese theology and beliefs and practices of the church in the twentieth century. This is evident in Zhou's analysis, which begins with an introduction of Nü Duo 女鐸, or Woman's Messenger, a monthly magazine targeting educated Christian females that was started by missionary Laura $\mathrm{M}$. White in 1912. The articles found in this periodical promoted a vision of "divine domesticity" that corresponded to the traditional Chinese notion of "men handling things outside and women in charge of inside" (nan zhu wai nü zhu nei 男主 外女主内). Zhou's discussion reveals a tension in how Christianity was presented for Chinese females. One the one hand, women were encouraged to be educated and modern. As noted by Stasson, churches and mission groups operated many of the first schools for girls, and converts were encouraged to give daughters greater freedom by, for instance, not binding their feet. At the same time, however, Christian females were being taught how to manage homes and instructed in the importance of raising children. This contradictory message for female Christians to be both modern and domestic is evident in many of the articles in this issue. Zhou ends her article by analyzing the native Chinese Christian response to the transformational Christian ideas related to family. The promotion of the "Christianizing the Home Movement," as seen in the pages of another Christian periodical in the 1930s, Budao zazhi 佈道雜志, reflects a Chinese institutional approach to transforming the family to align with Christian ideals.

This movement receives even greater attention in Amy O'Keefe's article. By tracing the history of the "Christianizing the Home Movement," a campaign initiated by a special committee of the Chinese-led National Christian Council (NCC), O'Keefe shows how Chinese Christian women were eager to take on institutional leadership roles. This campaign framed the home as a microcosm 
of both the Chinese nation and the church and called upon women in particular to endeavor to strengthen the nation and the church through their efforts in the home. The "Christianizing the Home Movement" actively opposed prostitution, concubinage, and gambling - vices connected to the destruction of the family - and distributed tens of thousands of publications, and in the 193os created a "Christianizing the Home Week" for churches to annually focus attention on strengthening family units.

While the first three articles deal with institutional or cultural change brought about by Christianity at the societal level, Sze-Long Aaron Wong's biographical sketch of Wong Tsing-yi is a reminder that the challenges and opportunities Christianity posed for Chinese culture were also played out on an individual level. Wong Tsing-yi was born into an influential Christian family in southern China; her grandfather and father served as a preacher and pastor respectively, and many of her siblings and cousins were notable intellectuals and public leaders. By focusing on the less well-known and female Tsing-yi, however, Wong provides a face for the revolutionary changes many Chinese Christian females experienced in the late Qing Dynasty. Tsing-yi's own education in mission schools led to her serving as headmistress of a girls' school, where she influenced numerous female students before dying at the young age of thirty-four. The story of Tsing-yi, recovered by Wong through genealogical writings and a few missionary publications, is an example of the enhanced agency that females in Christian families often experienced. Childhood education, unbound feet, and the opportunity to work outside of the home were experienced by Tsing-yi, and other Christian females, decades before they became culturally acceptable in the New Culture Movement.

The final article in this issue adds temporal, geographic, and theological balance to the topic of the family in Chinese Christianity. Eva Salerno's fieldwork among Chinese Catholics in Paris and Milan reminds us that issues related to the family are central to understanding Chinese Christianity in contemporary global settings. An interesting finding in Salerno's ethnographic study is that many Chinese Catholics in Europe trace their religious heritage back to ancestors in China many generations removed. This is particularly significant because much of the scholarship on overseas Chinese Christian communities in the West frames church membership as part of the process of assimilation to the dominant culture (e.g., Yang 1999, Guest 2003, Cao 2005). Salerno's article on Chinese Catholics in Europe, however, shows how Christianity is often part of the cultural tradition that immigrant Chinese communities hope to hold on to from their native regions.

Taken together, the research presented in this issue reveals both the role played by Christianity in shaping modern Chinese concepts related to the 
family, as well as how traditional Chinese values have influenced Chinese Christianity over the past century. The fusion of traditional Chinese and Christian worldviews, the progression from foreign missionary control to Chinese leadership, the struggles of living as a Chinese Christian in a secularizing Western society, and the contradictory message for Chinese Christian females to be both modern and domestic are some of the points of tension found within these articles. It is my hope that this issue will spur other scholars to recognize the importance of family in understanding Chinese Christianity, both in the past and today.

\section{References}

Cao, Nanlai. 2005. "The Church as a Surrogate Family for Working Class Immigrant Chinese Youth: An Ethnography of Segmented Assimilation." Sociology of Religion 66 (2): $183-200$.

Guest, Kenneth J. 2003. God in Chinatown: Religion and Survival in New York's Evolving Immigrant Community. New York: New York University Press.

Yang, Fenggang. 1999. Chinese Christians in America: Conversion, Assimilation, and Adhesive Identities. University Park, PA: Pennsylvania State University Press. 